1992

\title{
Dating an III-Fated Journey: Synesius, Ep. 5
}

Jacqueline Long

Loyola University Chicago, jlong1@luc.edu

Follow this and additional works at: https://ecommons.luc.edu/classicalstudies_facpubs

Part of the Classics Commons

\section{Recommended Citation}

Long, J. (1992). "Dating an III-Fated Journey: Synesius, Ep. 5." Transactions of the American Philological Association 122, p. 351-80.

This Article is brought to you for free and open access by the Faculty Publications and Other Works by Department at Loyola eCommons. It has been accepted for inclusion in Classical Studies: Faculty Publications and Other Works by an authorized administrator of Loyola eCommons. For more information, please contact ecommons@luc.edu. \section{(c) (i) $\Theta \Theta$}

This work is licensed under a Creative Commons Attribution-Noncommercial-No Derivative Works 3.0 License. (c) American Philological Association, 1992. 


\title{
Dating an Ill-Fated Journey: Synesius, Ep. 5
}

\author{
Jacqueline Long \\ The University of Texas at Austin
}

Synesius passed his life as one of the most important men in Cyrene. He was born into a wealthy family that claimed descent from the founding Heraclids (e.g. Catast. 303A). On one occasion he was chosen as Cyrene's ambassador to the imperial court at Constantinople. During this period the revolts of Tribigild and Gaïnas toppled Eutropius from seemingly absolute power behind Arcadius' throne; Synesius watched national politics unfold from a distinctive perspective, which he recorded in his De Regno and De Providentia. They are unquestionably important historical sources, but interpretation of them is complicated by the erudition and Neoplatonic philosophy artistically shaping their emphatic partisanship. Synesius' other treatises also reflect rhetorical and philosophical interests he had evolved as a student of the pagan Hypatia. Synesius' poetic hymns phrase Christian ideas in Neoplatonizing terms. The citizens of Ptolemais eventually made Synesius their bishop. In this position, as his letters show, he not only represented the patriarch Theophilus in pastoral disputes, but also deployed the authority of the Church against abusive governors and helped to organize the defense of his see against invading barbarians. 1

One hundred fifty-six extant letters represent Synesius' correspondence through all these periods of public and intellectual activity. They include formal greetings and recommendation letters, the standard fare of late antique epistolography, but also letters forwarding Synesius' literary works to friends, personal reminiscences and invitations, family news, his reservations about undertaking the bishopric, pastoral reports, a decree of excommunication, pleas on behalf of Pentapolis and accounts of its defense. He employs conventional elegances in formal letters, but his personal letters express strong emotions ranging from warm affection for friends and family and passionate

\footnotetext{
${ }^{1}$ E.g., respectively, Epp. 66, 67, 76; 41, 42, 72, 79; 62, 78. I cite Synesius' letters according to the edition of A. Garzya, Synesii Cyrenensis Epistolae (Rome 1979; text also available with Italian translation facing but without critical notes in Garzya's Opere di Sinesio di Cirene [Torino 1989]). Garzya followed the MSS. arrangement of letters against the traditional numerations of Migne, $P G$, and R. Hercher, Epistolographi Graeci (Paris 1873; see Garzya 1979, xxxiii; concordancu in Roques 1989, 253-4). In particular, Ep. 5 Garzya was traditionally $E p .4$ and is so identified in scholarship before 1979. Druon numbered the letters according to his own chronology for them, so that $E p$. 16 Druon $=E p .5$ Garzya.
} 
enthusiasm for the ideal of philosophy to despair over the deaths of his sons. He manipulates tone to suit his subjects, writing with careful soberness when deliberating over his bishopric or with dramatic boldness when defending his home. He draws scenes vividly. Jests and literary allusions further enliven many letters.

Ep. 5 displays particularly high literary polish. Synesius relates to his brother Euoptius a series of disasters that befell him on a multiply jinxed voyage from Alexandria to Cyrene. As news of a journey, it parallels the shorter, ordinary Ep. 53, in which Synesius reports a quick five days' sailing from Cyrene to Alexandria. Ep. 5 not merely describes the events of its trip but also ties them together with a cord of superstitions. Many details function emblematically and some appear to a degree fantastic, although Synesius never strays into outright impossibility. He implies that his misfortunes vindicate folk beliefs before Euoptius' skepticism $(11.6,26.9-10)$. Lively writing and rich texture of allusion frame his half-ironical conceit engagingly. A specific account of the days of sailing creates chronological particularity. Synesius' precision could be only a fabulist's gambit, but it does not play against extravagant fiction within his tale itself, as for example does Lucian's in the Vera Historia. Synesius' other letters all appear factual, though by no means dry. If the chronological allusions of $E p$. 5 yield a credible date, it would be reasonable to consider that Synesius' more fanciful details merely embroider fact rather than fabricate completely. If so, the date of $E p .5$ will help to fix other points within the mostly relative chronology of Synesius' correspondence and of his biography. More certain knowledge about his life in turn will guide interpretation of his other works.

I shall begin by summarizing Ep. 5 itself, paying attention to the chronological indications Synesius gives and to how he combines realia and folklore. Traditional conceptions add to the dramatic color and emotional impact of events. They relate integrally to the whole letter. Next I will review the last century's scholarly debate over the date of the letter, so as to show that the dates proposed, in 401, 402, 404 and 407, are either wrong or have been inadequately demonstrated. Finally, working systematically within the framework established by my predecessors, I will advance new arguments for a choice of two possible dates in 401 .

\section{The Journey and its Telling}

Synesius begins with the fact that before his ship even left the harbor it ran aground two or three times. He reflects that he should have heeded this nautical equivalent of tripping on the threshold (11.4-5). But he refused to let Euoptius laugh at him for backing out of the trip, and now he is stranded between 
Alexandria and home. Further omens abound hyperbolically. Amarantus, the ship owner and pilot, was bankrupt and accordingly had a death-wish. He and the crew numbered thirteen. Fear of thirteen is thinly attested in antiquity, but only this superstition explains why Synesius counts. ${ }^{2}$ Amarantus and more than half the crew were Jewish: Synesius calls them "an outcast race that believes that they are being pious if they are responsible for as many Hellenes as possible dying" (12.9-11). The remainder were hopelessly inexperienced landsmen. All alike were crippled in some bodily part. To Synesius' horror, they cheerfully publicized this jinx by hailing one another not by name but after their deformities.

Against this ugly and ominous sight Synesius juxtaposes a glimpse of his fellow-passengers: about a third of the fifty or so were women, and many of them young and pretty. But not to worry, Synesius hastens to assure Euoptius: they had stretched between them the impregnable barrier of a tattered sail. And Amarantus' sailing would have kept Priapus chaste, so afraid were they all for their lives. Wry sarcasm spices both mortal peril and sexual temptation.

Then the drama begins. Amarantus had no sooner managed to clear the harbor than he headed for the rocks of Taphosiris under full sail. The passengers cried out and forced him to steer away at the last moment. Now, more alarmingly still, he veered out to the open sea. The passengers panic again. Amarantus curses them terribly, like a Titan in a tragedy. Synesius pacifically urges Amarantus to hug the shore in safety. But Amarantus stubbornly persisted. Then a gale blew down from the north, confirming all the passengers' worst fears. ${ }^{3}$ To make matters worse, as soon as the sun set Amarantus abandoned the tiller because it had become the Jewish Sabbath. Synesius meticulously explains that Jewish law forbids manual labor on the

\footnotetext{
${ }^{2}$ Cf. R. Pack, "Folklore and superstition in the writings of Synesius," CW 43 (1949) 52. Garzya 1978, 128 discounted ancient triskaidekaphobia, but Roques 1977, 274 n. 2 rightly linked this passage with Synesius' more plainly superstitious reference to the date of the second

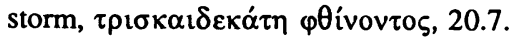

${ }^{3}$ More importantly, their survival demonstrated the true wisdom of Amarantus' navigation, though Synesius knew too little about sailing to recognize it: L. Casson, "Bishop Synesius' voyage to Cyrene," American Neptune 12 (1952) 294-6. See further Casson's "Studies in ancient sails and riggings," Essays in Honor of C. Bradford Welles, Am. Stud. Pap. I (New Haven 1966) 43-58; F. Meijer, "The ship of the bishop Synesius," IJNA 15 (1986) 67-8. P. $\mathrm{X}$. H. Simeon, Untersuchungen zu den Briefen des Bischofs Synesios von Kyrene, Rhetorische Studien 18 (Paderborn 1933) 62-78 compared Ep. 5 with traditions of literary ecphraseis of storms at sea.
} 
night preceding the Sabbath and on the day itself. Amarantus accordingly ignored his passengers' hysterical pleas and threats, and sat reading the Torah. ${ }^{4}$

Finally, however, in the middle of the night Amarantus decided that the storm now threatened their lives, at which point the Law enjoins action. While the passengers prepared for death he rode the storm. Soldiers travelling on the ship prepared to fall on their swords. Women distributed their jewelry to the other passengers, so that each corpse might carry a fee for its own burial. 5 Synesius contemplated Homeric references to death by drowning. He insists that he regretted dying only because he would then be unable to repay a debt to "the Thracian" whose guest he had been (18.14-18). Luckily for his sense of shame, in the morning the weather abated somewhat, and they were able to reduce the sail. Within four hours after daybreak they landed in a desert area. They waited there two days for the sea to grow calmer.

Synesius' troubles were far from ended (20.3-15):

Setting out right as day began, we kept on sailing with a wind from our stern for that whole day and the following day. As the latter was ending, the breeze left us and we were distressed. But we were about to long for a calm. On one hand, it was the thirteenth of the waning month. On the other, a great danger was impending, since both the conjunction [of the stars] and the notorious elements ${ }^{6}$ (which no one, they say, who was sailing would not fear) were rushing to coincide at the same point. And when we should have been taking harbor-dues, we had unawares gone running out onto the sea again. The upset was started by the northern winds and it rained greatly throughout the night of the conjunction. Then the winds were turbulent and the sea was stirred up.

The storm broke their sailyard and drove them along all the next day and night, till at the second cock-crow before dawn they ran very close to a rock a short distance offshore. The passengers rejoiced, but the sailors regarded it as the worst danger yet. At dawn however, an aged native appeared and guided them into safe harbor at Azarium. The same man rescued four other ships in the same way before the day was out. On the next day other ships put into the

4Pack (above, n. 2) 53 suggested that Amarantus was applying Jewish magic against the supernatural dangers of the Sabbath eve, but it seems unlikely that Synesius would so carefully define one Jewish observance and omit this one entirely, if he meant to allude to it too.

${ }^{5}$ Synesius 18.10-13 explains this custom, an ancient commonplace (e.g. R. G. M. Nisbet and M. Hubbard, A Commentary on Horace: Odes Book I [Oxford 1970] 317-37 on Carm. 1.28 ), as carefully as the Jewish Sabbath observances; it is not safe to assume that either was unknown to him or to Euoptius.

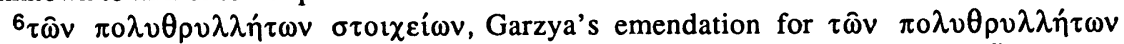
$\tau v \chi \alpha i \omega v$ of the MSS: see Garzya 1978 and below. Garzya also bracketed $\tau \hat{\omega} v$ $\alpha \sigma \tau \rho \omega v$ at 20.9 . 
harbor; "and now," Synesius continues, "we are a full-fledged fleet in a small shipyard" (22.8-9).

Their next peril was starvation. No one had anticipated that the trip would take so long, and they had all used freely the moderate amount of food that had been packed. The old native saved them again by showing them where to fish. The pickings were slender, though Synesius notes that fishing has kept them alive for seven days so far. Men, women and children hoarded jealously whatever they caught.

At last another curious twist of fate brought them abundance. The women of Azarium, Synesius explains, have outsize breasts on which the nipples point upwards, so that they sling their babies over their shoulders to nurse them. They distrust their men's report that women from outside their territory are shaped differently. If ever they encounter a foreign woman themselves, they show her every kindness in order to persuade her to let them examine her bosom. They spread word of the marvel. Others come in crowds to see for themselves, all bringing gifts. One especially skinny and unabashed slave in Synesius' party made herself immensely popular with them, being summoned to visit in turn the richest women's houses for three successive days. Soon there was more than enough food for all. Synesius insists to his brother that he himself takes no food from the women, "both for your sake and so that I may not have an armistice with them and then, when I have to forswear, have difficulty refusing" (24.1-4). He accepts fish from the children and other men in the party, who can spare it because they do share the women's gifts.

This episode relaxes the high drama of the storm into comedic fantasy, much as Odysseus limps battered from the sea and is received in magical Phaiakia. Intriguingly, the Azarian women exhibit some likeness to Al-Auzza, a pagan Arab divinity before Islam. She appears in later folklore as an old woman with disheveled hair who occasionally throws her pendulous breasts up over her shoulders. The hero is thus enabled to sneak up on her and suckle before she can prevent him; once he has done so she considers him her fosterchild and helps him in his quest. ${ }^{7}$ The Azarian women too have breasts distinctively oriented upwards, whose peculiar situation indirectly inspires them to provide the travelers with food and help. Synesius accounts for the details fully rationalistically, and yet they border on the fantastic. It would fit with the other folk beliefs Synesius incorporates into $E p$. 5 if the women too reflected similar traditions, possibly stories Synesius and Euoptius heard in

\footnotetext{
7 See H. M. El-Shamy, Folktales of Egypt (Chicago 1980), 55 and 58; I. Bushnaq, Arab Folktales (NY 1986), 68-9, though the story representing the motif in this collection does not state explicitly that the She-Ghoul's breasts have been displaced (see 92).
} 
their shared childhood. Such a fabulous coloring would not mean that the Azarian women do not also reflect something Synesius really experienced. ${ }^{8}$ Whatever their proportions of fantasy and fact, they may provide a link helping to trace Al-Auzza back to native Egyptian or Libyan traditions.

Synesius closes with greetings to friends including "the holiest and most blessed lady philosopher," meaning his teacher Hypatia; this reference recurs to his leaving Euoptius behind in Alexandria. ${ }^{9} \mathrm{He}$ concludes by wishing that Euoptius may never go sailing, "but if it is ever absolutely necessary, at least don't do it when the month is waning!" (26.9-10).10 This warning evokes again the travelers' forlorn situation at the letter's beginning. Synesius never finally resolves all his tensions by bringing the travelers safely home; this odd lapse tends to confirm the outline of his story as fact, despite the Azarian women.

Synesius tells his tale superbly. The ship speeds thrillingly from crisis to crisis. Direct speech lends epic immediacy. Allusions to Amarantus' financial malfeasance pepper the high adventure with Synesius' very human irritation. As Synesius describes the first storm, the devout perversity of Amarantus' actions and the sage and erudite meditations on death that Synesius claims for himself (with one socially responsible scruple) each function in counterpoint to the other passengers' hysterical preparations for death. This rhetorical interplay of contrasting behaviors from different cultural traditions helps to characterize the parties and to raise dramatic tensions. They are released suddenly when the storm diminishes.

When the voyage resumes and begins its second stage, two days of clear sailing temporarily reverse the first bad start from Alexandria; but Synesius instantly notes astrological omens that threatened even worse disaster than did the human misfortunes with which the trip began. This time the ship itself is crippled. Motifs are reversed again when the passengers rejoice at what the sailors think their greatest danger. But once more the worst passes away.

Synesius continues the motif of danger in the third stage of his voyage with a moral threat particular to himself. The passengers do not live luxuriously from their fishing, but they avert starvation readily. Synesius' problem is rather to avoid contact with the female passengers, when not only do they possess their usual charms but also they transmit to the others the food

${ }^{8}$ Cf. G. J. de Vries, "Maiorem infante mamillam," Mnemosyne 3d ser. 12 (1945) 160.

925.19-20, cf. 11.6-9; PLRE II.575-6, "Hypatia 1."

10M. V. Anastos, "Pletho's Calendar and Liturgy," DOP 4 (1948) 183-305 at page 247 and n. 346 assembled a dossier of late antique superstitions against the last days of the month. 
given to them by the Azarian women. ${ }^{11}$ Thus Synesius returns to the idea of sexual temptation broached in the beginning of the letter (12.19-13.7). This theme infuses an element of suspense into the entertaining exotica surrounding the travelers' last rescue. The relaxed, confident tone of the happy ending and the pleasingly ordinary triviality of greetings to friends counterbalance any seriousness in Synesius' final warning. It merely epitomizes wryly the folly of his own journey. This rueful humor completes the circle of Synesius' thought back to his introduction, and ties Ep. 5's package of adventure and folk superstitions neatly together.

\section{The Date}

Synesius' artistry in Ep. 5 deserves attention in its own right. Even a historical study must consider how he combines realistic and fantastic elements, lest the unusual women of Azarium provoke rejection of all Synesius' astronomical and chronological detail. That detail needs to be tested against calendars and astronomical tables to see if it can produce a date that fits with the known facts of Synesius' biography; if it can, it will establish another, badly needed, chronological reference point.

Otto Seeck in 1894 did not account for the internal detail of Ep. 5 itself in dating it. He argued that Synesius' embassy to Constantinople spanned the years 399 to 402 (458-60), and assumed that Synesius visited for two years in Alexandria on his way home (cf. Ep. 123.211.9-12); accordingly, he placed Ep. 5 in 404 (470). Georg Grützmacher in 1913 accepted Seeck's basic date of 404, assumed that Synesius always used Egyptian months, and placed the letter on 28 January 404.12 But as Ingeborg Hermelin pointed out in 1934, when Synesius uses Egyptian months, he counts in the normal fashion, from the beginning of the month. Hermelin argued cogently that by "the thirteenth of the waning month" (20.7) Synesius means a lunar month calculated from the full moon. ${ }^{13}$ Although a lunar month usually is counted from when the "new" crescent moon first reappears, as it grows to fullness about fifteen days later, until it ends on the dark of the moon at the next conjunction, Synesius counts

\footnotetext{
${ }^{11}$ Cameron, 360 supposed that Synesius must avoid the Azarian women, but Synesius states clearly that the Azarian women give things to the women travelers and that they in turn pass

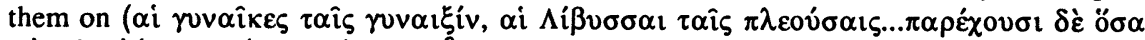

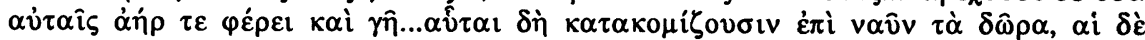

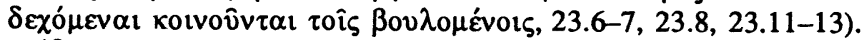

${ }_{12}$ G. Grützmacher, Synesios von Kyrene: ein Charakterbild aus dem Untergang des Hellenentums (Leipzig 1913), 74 n. 3.

${ }^{13}$ Hermelin, 31-35; cf. Anastos (above, n. 10), 228-30; Bickerman², 16-19; Samuel, 1-18 (particularly clear on many matters of calendrical astronomy, with helpful diagrams).
} 
from the full moon in order to incorporate a second unlucky thirteen into his tale. ${ }^{14}$

Further, Hermelin adduced an ancient statement to the effect that the moon is full on the 15th of a lunar month. ${ }^{15}$ She calculated accordingly that Synesius' "thirteenth" corresponds to the 28th day of a lunar month. She then identified the "night of the conjunction" (20.13-14) following this "thirteenth" as "die Nacht vor dem Neumond, der folglich auf den 29. und letzen Tag des Monats fiel." 16 Thus she concluded that Synesius delineates a lunar month that, calculated in the ordinary way, is 29 days long. She cited additional evidence that a new moon was considered unlucky for sailing. Unfortunately her authority is imprecise. Nor is it all that antiquity has to offer. For example, the first century A. D. astronomer Geminus affirms that the full moon appears anywhere between the 13th and the 17th of the lunar month. ${ }^{17}$ In actuality, if a lunar month begins on the day following the night of the conjunction, the full moon occurs variably on the night of the 14th or 15th day of a 29-day lunar month and variably on the night of the 14th, 15th or 16th day of a 30-day lunar month. ${ }^{18}$ If the date "of the waning moon" is counted from the day

${ }^{14}$ Hermelin, 35 first implied this interpretation of Synesius' usage; explicitly, Cameron, 357. Arat. Phaen. 733-39, for example, attests the standard reckoning of the lunar month in

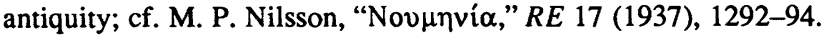

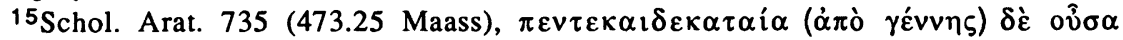

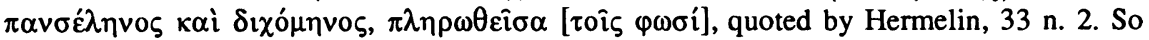
too Schol. ad Syn. Ep. 4(5).643.12s., Garzya, "Nuovi scolî alle Epistole di Sinesio," BPEC n.s. 8 (1960) 47-52 = Storia e interpretazione di testi bizantini: saggi e ricerche (London 1974) XXVIII, here page 49; cf. Garzya 1978, 126 (but the date of the lunar month cannot so simply be transferred to a month of the Julian calendar). The references assembled by A. Mommsen, Chronologie (Leipzig 1883) 98-102, show that the full moon was reckoned variably; see discussion below.

${ }^{16}$ Hermelin, 33-34. She avoided popular speech's confusion between the conjunction (when earth, moon and sun are perfectly aligned so that the sun's light illuminates only the side of the moon away from the earth and the side visible from the earth is entirely dark) and the first reappearance of the moon as a crescent (which defines the first day of the new lunar month). The full moon is visible at its conjunction, when moon, earth and sun are aligned so that the side of the moon visible from the earth is entirely illuminated.

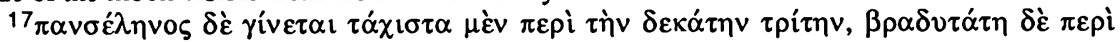

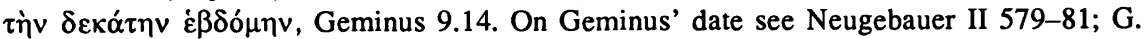
Aujac, Géminos: Introduction aux phénomènes (Paris 1975) xix-xxiv identified Geminus with a correspondant of Dionysius of Halicarnassus on weak grounds that cannot withstand Neugebauer's astronomical precision.

${ }^{18}$ These calculations are based on the table of "new" and "full" syzygies (conjunctions) provided by Goldstine. Geminus appears to accomodate inaccuracies of perception with the extra days to which his interval extends. Samuel, 8-10 and Bobrovnikoff, 58-61 discussed objective reasons why the new crescent may be perceived only following a 16 to 36 hour interval after the conjunction (abstracted below); many of these considerations apply to 
following the night of the full moon, Synesius may designate either the 28th of a 29-day lunar month (counting from a full moon on the 15th) or the 29th of a 30 -day lunar month (counting from a full moon on the 16th).

Synesius' "thirteenth of the waning month" may not even be limited so strictly as this. If Synesius observed rather than calculated his last full moon and present new moon conjunctions, he may have fallen into the margin of error for naked-eye astronomy suggested by Geminus' two extra days of variability in the appearance of the full moon. If he did, all 29-day lunar months and all 30-day lunar months except those with a perfectly full moon on the 14th become eligible. Even if he calculated the dates, ancient formulae seem to have tolerated inconsistencies of a single day (Samuel, 14-15, 171-88). It is probably prudent not even to exclude 30-day months where the moon was full on the 14th. The fact that Synesius designates the penultimate day of the month is inherent in the fact that the conjunction occurs on the following night. ${ }^{19}$ All months should be considered.

Hermelin herself did not pursue further her conclusions about $E p .5$ but others drew assumptions from her work when they sought to date the letter. Joseph Vogt (407-8), like Grützmacher before him, showed that Synesius makes his "thirteenth day" a Tuesday. Vogt accordingly dated Ep. 5 by the fact that there was a conjunction on the night of Wednesday 29 May 401 . He seems thus to insert an extra day into Synesius' narrative. In fact the dates are not inconsistent, for the conjunction occurred very early in the morning of Wednesday 29 May $401 .{ }^{20}$ Synesius would have observed it during the night following the Tuesday. He does not divide days and nights at midnight like modern calendars but distinguishes them as natural units, as he shows when explaining that Jews reckon the Sabbath from nightfall to nightfall (15.1213).21

distinguishing the first waning of the moon from the full. M. P. Nilsson, Primitive TimeReckoning, Acta Soc. Hum. Litt. Lund I (Lund 1920) 151 remarked on the subjective difficulty of the distinction.

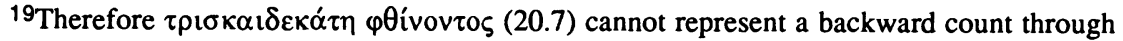
the second half of the month, as in the last decads of months (with $\varphi \theta$ ivov $\tau \circ \varsigma$ or a synonym) in the various Greek calendars assembled by Samuel.

${ }^{20}$ Goldstine 117 calculated the conjunction at 5:57 A.M. for an observer at Babylon. Relative to the local appearance of the day, which naturally differs across the surface of the earth, the conjunction would have been observed 58 minutes "earlier" at Alexandria (viii). Synesius was still a little further west, off the coast somewhere between Alexandria and Cyrene; he would have observed the conjunction approximately one hour "earlier" than the time given by Goldstine.

${ }^{21}$ The Jews reckon days using the "evening epoch": cf. Neugebauer III 1067-69. Bickerman', 13-14 observed that for ordinary purposes the Greeks and Romans thought of a 
Vogt noted that his date for Ep. 5 contradicts Seeck's argument that in the years 399 to 402 Synesius was in Constantinople on embassy from Cyrene to the court of Arcadius, but he did not answer Seeck any further. Vogt also admitted but did not resolve a possible ambiguity in Synesius' account of days which too would overthrow his date for Ep. 5. Denis Roques $(1977,280)$ cited Seeck alone to refute Vogt. Roques himself sought to date Ep. 5 more systematically. He followed Hermelin and Vogt to identify a Tuesday that is the 28th of a 29-day lunar month. But he inferred that the new moon continues to exercise its malign influence until Synesius' ship is brought to shore near Azarium: therefore he looked for a new moon marking the first of a lunar month on the next Thursday. Since Roques spoke of the new crescent where Hermelin and Vogt referred to the conjunction, it may be well to insert a chart here to show that their reckonings conform. The chart follows the logic of the lunar calendar, determined by the appearance of the moon, in using the evening epoch to reckon each night with the following day.

\begin{tabular}{lll} 
Day of Week & Day of Lunar Month & \multicolumn{1}{c}{ Event } \\
\hline Tuesday & penultimate & second day clear sailing; calm near sunset \\
(night) & last & conjunction; rain \\
Wednesday & last & storm continues \\
(night) & first & storm continues; presumed new crescent \\
Thursday & first & safe arrival at Azarium
\end{tabular}

Roques generated a list of astronomically possible dates between 395 and 415, the outside limits for Synesius' correspondence. He omitted 400 and 401, relying on Seeck's date for Synesius' embassy. Roques parted from Seeck in dating Synesius' two-year visit in Alexandria to 403-404;22 he accordingly excepted 403 too from his calculations. Roques also eliminated all possible dates falling in the summer, on the grounds that it cannot have rained in the region between June and September. He further excluded dates falling outside the normal sailing season. Other theoretically possible dates conflicted with his conclusions from other letters, and he was left with a new moon on Thursday 17 October 407. He concluded that Synesius set sail on Friday, 11 October 407, and that he wrote Ep. 5 while still stranded in Azarium on Wednesday, 23 October 407.

One true and one false problem result from Roques' looking for the new moon rather than the conjunction. The false problem arises because the new

day as running from dawn to dawn (the "morning epoch") even while their civil calendars reckoned in terms of the evening epoch.

${ }^{22}$ Cf. Ep. 123.211.9-10. Roques 1977 referred to Lacombrade, 136-7, but see now Roques 1989, 17-18; against Seeck, 460. 
crescent does not invariably appear on the night after the conjunction, as Hermelin and Roques assumed. ${ }^{23}$ The moon always takes several hours to revolve about the earth far enough from the point of conjunction for it to begin to reflect light from the sun onto the earth. The angle between the orbits of the earth about the sun and of the moon about the earth changes as the satellites proceed in their orbits, and changes the rate at which they move out of alignment with the sun. The similarly changing distance between the earth and moon also changes this rate. The interval between the conjunction and the appearance of the new crescent accordingly varies. Local atmospheric conditions and the observer's eyesight both affect his ability actually to perceive the moon. Finally, although both the conjunction and the first reflection of sunlight thereafter can occur at any hour of the day or night, either or both may temporarily be obscured by the direct sunlight of daytime. The astronomical events can be perceived only approximately, on the nearest night. Nevertheless for purposes of calculation the ancients generally assumed, like Hermelin and Roques, that the new crescent did appear on the day after the conjunction. Geminus obviously dates the month from the conjunction when he observes that "the crescent moon appears at the earliest on the first day of the month, at the latest on the third." 24 As Hermelin has shown, Synesius uses the language of lunar months; whether he counts the days according to astronomical phenomena he actually saw, or whether he calculates the lunar period, a modern researcher can follow him by means of an accurate chart of the ancient conjunctions. ${ }^{25}$

Roques took his dates from the tableau perpétuel des Lunes juliennes given by Paul Couderc after the Paschal calculations of the sixth century churchman Dionysius Exiguus. ${ }^{26}$ The table relies ultimately on the close equivalence, recognized in Greece by the fifth century B. C., of 19 solar years with 235 lunar months. ${ }^{27}$ As Couderc admitted, this equivalence is not perfect:

\footnotetext{
${ }^{23}$ See Samuel, 8-10; Bobrovnikoff, 58-61.
}

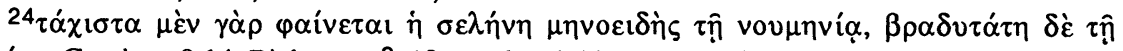
$\tau \rho i \tau n$, Geminus 9.14. Bickerman², 18 translated this sentence, "the new moon is visible at the earliest one day, at the latest three days after the conjunction." Similarly too, for example, Thuc.

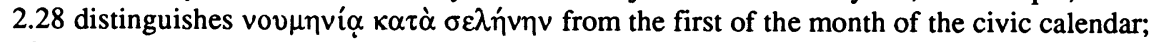
cf. Samuel, 57-58.

${ }^{25}$ See Goldstine, Introduction.

26P. Couderc, Le calendrier, 2nd ed., Series Que sais-je? (Vendôme 1948) 88-93 and fig. 4 (Roques 1977, $276 \mathrm{n}$. 1 cited a fourth edition of 1970, but I have been unable to obtain a copy). Dionysius Exiguus revised the Paschal calendar in 526-531: see V. Grumel, La chronologie (Paris 1958), 36-40.

${ }^{27}$ Meton introduced the principle of a 19-year cycle in 432 B. C.: see Neugebauer II 622-4 with Samuel, 42-49, 52-55. 
the table lags behind the true cycle of the moon by about an hour and a half every 19 years, so that by the end of about 300 years it is a full day behind. Roques acknowledged that it might be out of phase for the time of Synesius, but he made no compensating correction. ${ }^{28}$ Couderc also explained that the table is based on the mean lunar period rather than the continually varying true period, so that individual dates are subject to an irregular error as well as the incremental error of the cycle. Couderc aimed only at approximation, when Synesius is talking about real phenomena. More precise calculation is needed to trace what he reports. Worst of all, Roques incorrectly understood Couderc's term "Nouvelle Lune" to refer to the first appearance of the new crescent moon, when the table actually gives the days of conjunctions. Thus Roques calculated the dates of conjunctions occurring on nights between a Wednesday and a Thursday. But Synesius places the conjunction of Ep. 5 on the night following a Tuesday. No date found by Roques conforms to Synesius' data. ${ }^{29}$ It is most unfortunate that his magisterial list has discouraged other scholars from examining Synesius' calendrical and astronomical data critically.

Roques' methodology was criticized on other grounds by Christian Lacombrade. ${ }^{30}$ Lacombrade objected that Roques excluded all summer dates by applying modern meteorological norms too strictly and without justifying their validity for the fourth and fifth centuries. Other arguments by which Roques excluded specific dates are also, in Lacombrade's opinion, too narrow and improbable: for example, the conventions of ancient epistolography refute Roques' argument from silence that Synesius cannot have written Ep. 5 in 404 since in that year he must have mentioned his wife. ${ }^{31}$ Lacombrade preferred to emphasize Synesius' debt to his Thracian host (18.14-18). Synesius elsewhere identifies a debt of 60 solidi which he borrowed from the Constantinopolitan

\footnotetext{
${ }^{28}$ Roques seems however to have misunderstood the extent of the lag, for he estimated it at "environ 33 H" (Roques 1977, 279 n. 4). About 125 years elapse between 400, a rough figure for the date of $E p$. 5, and Dionysius Exiguus' reform: the table would diverge from the true lunar cycle by about 10 hours. But if Dionysius only extended the Paschal calendar calculated for Cyril of Alexandria ca. 431, without correcting it by current lunar observations, the table would be only a few hours in error for Synesius.

${ }^{29}$ Compared to Goldstine's more precisely calculated times, corrected for Synesius' location (see above, n. 20), 9 of Roques' Thursdays correspond to nights between a Wednesday and a Thursday when a conjunction could be observed, and only 2 to Thursdays following a conjunction observable between Tuesday and Wednesday. 4 diverge more widely from a conjunction and doubtless reflect other inaccuracies in Couderc's table.

${ }^{30}$ Lacombrade, "Encore la lettre 4 de Synésios et sa nouvelle lune," REG 91 (1978) 564-67.

${ }^{31} \mathrm{Cf}$. Roques 1977, 284. Synesius in fact almost never mentions his wife (Ep. 105.187.914, Ep. 132.229.7; cf. Hymn 7.33-34); like the wife of his Osiris, her existence virtually remains to be inferred only from the rare appearances of her sons (Prov. 105D, 93.2-6 Terzaghi).
} 
Proclus when fleeing from Constantinople (Ep. 129.220.8-12; cf. Ep. 61). Lacombrade argued that Synesius must have repaid this debt as soon as possible, and that therefore he could only feel the anxiety about it he expresses in Ep. 5 while returning home from Constantinople. Since Lacombrade, like Roques, followed Seeck in dating Synesius' return to 402, he returned to the date for $E p .5$ that he earlier had proposed in vaguer terms, and selected from Roques' list the new moon falling on Thursday, 14 August 402.32 Thus despite his other objections, Lacombrade ended by importing Roques' basic astronomical and calendrical errors into his own dating.

T. D. Barnes and Alan Cameron have now shown conclusively that Synesius' embassy spanned the years 397-400, not 399-402 as in Seeck's chronology. ${ }^{33}$ Cameron also considered $E p$. 5. He shared Lacombrade's objections to Roques' date and Lacombrade's preference for a date on Synesius' journey home from Constantinople. Accordingly he concurred with Vogt, though stating the date by reckoning of the morning epoch as Tuesday, 28 May 401.

More recently Roques $(1989,181-6)$ has reaffirmed his dating against Lacombrade. He accepted Garzya's emendation $\tau \hat{\omega} v \pi 0 \lambda v \theta \rho v \lambda \lambda \dot{\eta} \tau \omega v$ $\sigma \tau 0 \iota \chi \varepsilon i \omega v$ for $\tau \hat{\omega} v \pi 0 \lambda v \theta \rho v \lambda \lambda \eta \dot{\tau} \omega v \tau v \chi \alpha i \omega v(20.10$; cf n. 6, above) but interpreted it differently, so as to support his earlier conclusions. Garzya (1978, 127-9) drew his proposal from the terminology of P. Mag. Par. 1.1303: on his view, Synesius attributes the storm to Ursa Major's being in the sky on the night of the conjunction and puns silently on the unexpressed Greek

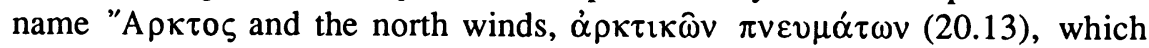

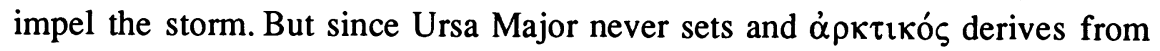
$\alpha \rho \rho \tau \sigma \varsigma$, this explanation is tautological and weak. ${ }^{34}$ Nor is Ursa Major associated with risks at sea. Roques preferred to identify Garyza's "notorious elements" as the Pleiades and Hyades. ${ }^{35}$ They were associated with storms throughout antiquity. Hesiod specifies that when they and Orion set at dawn, sailing is to be avoided (OD 619, cf. 615). Other evidence confirms that in late

${ }^{32}$ In fact, the date by the evening epoch of a conjunction observable from Bablyon at 2:08 A.M. on 15 August (Goldstine, s.a. 402); cf. Lacombrade, 130-36. Synesius' return, Lacombrade, $100-01$.

${ }^{33}$ T. D. Barnes, "Synesius in Constantinople," GRBS 27 (1986) 93-112; Cameron, art. cit.

$\rightarrow$ P. J. Heather, "The anti-Scythian tirade of Synesius' de Regno," Phoenix 42 (1988) 152-72 demonstrated that Synes. Reg., which purports to be Synesius' speech presenting aurum coronarium on this embassy, evokes political situations of 397/8.

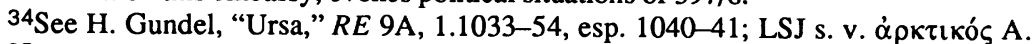

${ }^{35}$ Roques $1989,183-4$ and $n .158$. 
antiquity, sailing did stop at precisely this point of the year. ${ }^{36}$ Since it is the stars' morning activity that ancient observers conventionally marked, on strict terms Roques' interpretation invalidates itself. The difficulties are to some extent nugatory: on the one hand Garyza's emendation is unnecessary, since Hermelin adequately explained the crux by the ill luck a thirteen notoriously would bring to the day of the conjunction, ${ }^{37}$ and on the other Roques embraced the reinterpreted emendation only as an auxiliary point. His dating rests essentially on his earlier arguments. More seriously, Roques ignored Cameron's article. ${ }^{38} \mathrm{He}$ also failed to reconsider the flawed basis of his calculations.

The problem cannot rest in this condition. In the pages that follow, I first review Synesius' account of the days of the voyage. To these data I apply Herman H. Goldstine's precisely calculated times of conjunctions, New and Full Moons 1001 B.C. to A.D. 1651 and a perpetual Julian calendar in order to generate a new list of astronomically possible dates for Ep. 5. Both 29-day and 30-day lunar months, with all their combinations of new and full moons, enter consideration. The complete list appears in the Appendix to this article. Finally I determine which dates on the list remain possible in the light of other relevant factors, such as the true dates of Synesius' embassy.

The first storm struck the day the ship left Alexandria. Synesius' careful explanation of the Jewish Sabbath reveals that this day was a Friday (15.1113). Amarantus refrained from work until the middle of the night (16.19). When the danger became critical, he took charge again and guided them through the storm. The next morning (19.4), therefore Saturday, the weather moderated. The ship landed "before it was four hours" (19.10). The precise time in modern terms depends on what time daybreak occurred and thus on how many hours of daylight were in the day, therefore on what time of year it

${ }^{36}$ Gundel charted the Pleiades' rising and setting times at different observation points and years in RE 21, 2.2503; cf. his "Hyaden," RE 82616 and 2619, and M. L. West, Hesiod: Works and Days (Oxford 1978) 253 and ad 383-4, 615; West's Excursus II lucidly explains the relevant astronomical technical terms. As observed from the latitude of Alexandria, ca. A. D. 400 the Pleiades set on November 10 or 11, Vegetius' extreme limit for open seas (4.39; cf. below); the Hyades and Orion follow the cycle a few weeks later.

37 Hermelin, 34-35; she, Roques 1977, 273-4 and Garzya 1978, 127-8 each reviewed earlier interpretations (cf. n. 2).

${ }^{38}$ Roques 1989, 19 n. 26 briefly dismissed Cameron's arguments on inadequate grounds. Roques himself recognized that Seeck was wrong to dismiss from consideration the evidence that Cameron exploited (Roques 1989, 17, by the shamefaced device of a parenthetical question mark); since the dates that Roques presumed for Synesius' embassy ground his chronology for the whole of Synesius' corpus, he cannot justly maintain that the internal consistency of his results validates one of their premises. 
was, ${ }^{39}$ which has yet to be determined; but it is safe to presume that the ship landed at some time in the mid to late morning. Synesius says that they remained in this desert place two days (19.20-20.1). This is the crux at which

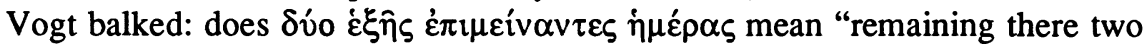
successive days" including the Saturday on which they arrived, or "remaining there for the next two days" after the Saturday?40 The absence of an article and the ancient habit of counting inclusively both argue for the former interpretation. Roques $(1977,271)$ preferred it on the grounds that, at whatever precise time the ship landed, more of the day remained than had passed. The travelers waited on land for the rest of Saturday and all Sunday.

The second stage of the voyage began at daybreak on the next day (20.34), therefore Monday. The ship sailed with a following wind "that whole day and the following day" (20.4-5), that is Monday and Tuesday. As Tuesday evening neared, it was becalmed (20.5). But it was the thirteenth day of the waning month and the new moon and other astrological danger signs hung over them (20.7-10); the winds rose from the north "and it rained greatly throughout the night of the conjunction" (20.13-14). Synesius indicates no lapse of time. The conjunction occurred on the night following the thirteenth of the waning moon, between a Tuesday and a Wednesday. This is the reference point from which the whole voyage must be dated. The storm continued throughout the next day, therefore Wednesday, and the following night until shortly before daybreak (21.2-4). At dawn the mastless ship was guided into harbor (21.11-12). It was now Thursday. Other ships were rescued during that day (22.3) and the next (22.6-7): the second stage of the journey is completed one week after Synesius left Alexandria, on a Friday.

Synesius reports the passage of time a little less clearly in the third stage

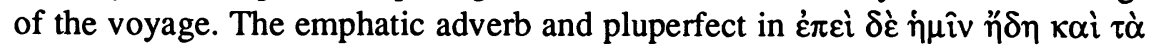
$\dot{\varepsilon} \varphi o ́ \delta \imath \alpha \kappa \alpha \tau \varepsilon \delta \eta ́ \delta o \tau o ~(22.10)$ suggest that his own ship was already out of food on the Thursday when it came to harbor, although the second maritime adventure of the narrative extends a day later to the arrival of the other ships. The slight overlap allows Synesius to distinguish the disparate episodes. Accordingly, the "seventh day now on which we have been living by fishing" (22.16) designates the next Wednesday, reckoning inclusively.

Roques dated the letter to this day, ${ }^{41}$ but in fact the intervention of the Azarian women must come later. Admittedly, Synesius uses present indicatives

\footnotetext{
${ }^{39}$ See Bickerman ${ }^{2}, 15$; Bobrovnikoff, 16-20; Neugebauer I $40-43$ and further II 706-24, 763-67.

${ }^{40}$ Vogt, 408; Lacombrade, $134 \mathrm{n} .10$ admitted the same difficulty.

${ }^{41}$ Roques 1977, 295; Roques 1989, 182.
} 
to describe the company surviving generally, the children prospering on small fish, and himself and the "Roman monk"42 thriving on limpets

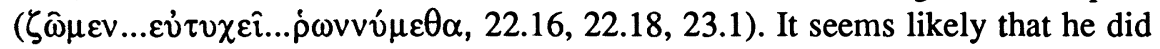
compose at that time a version of $E p .5$ that described the two ill-fated spurts of actual sailing and ended pathetically with the wrecked travelers bravely grubbing for austere viands. But next an imperfect indicative, adverbially reinforced, summarizes this harsh existence as bygone, and Synesius contrasts it with present bounty $(23.3-6)$ :

At first we lived shabbily from our hunting, with everyone clinging to anything at all that he might grab, and no one gave presents to anyone; but now we are all in more ungrudging circumstances, for such reasons as these.

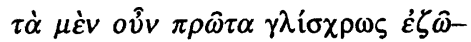

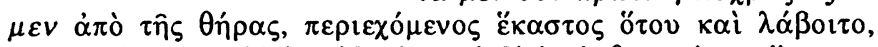

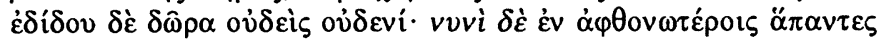

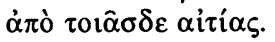

Synesius proceeds to explain how the women of Azarium befriended the female travelers. It is possible that he ignored some initial contact between them when he depicted the travelers struggling against privation on "the seventh day now," but the rescue cannot yet have been complete. Synesius' change of tenses marks an undefined lapse of time. He says specifically that the thin slave toured wealthy houses for three days (25.7). His story implies that even before, the Azarian women exchanged news of the foreigners for some period. The new generosity with which his fellow-passengers supplement Synesius' fishing also confirms that the travelers' situation has changed (23.13-24.1). Ep. 5 was finished in its present form no earlier than Friday, the third day counting inclusively after Wednesday, "the seventh day," and more likely several days later still. Apparently Synesius, having had no opportunity meanwhile to send his letter, revised it when new material offered itself. ${ }^{43}$

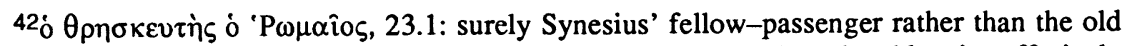
native who rescues the travellers, pace Druon, 445 . Synesius describes the old native effusively

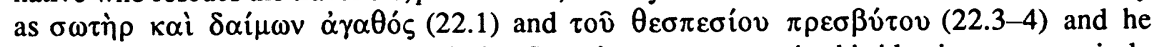
obviously lives ascetically (22.13-14), but Synesius never ascertains his identity more precisely

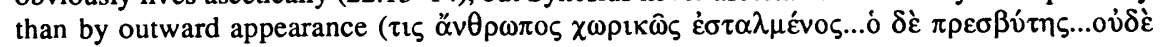

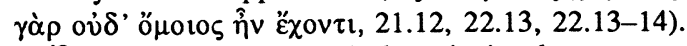

${ }^{43}$ The break in chronological continuity also suggests that, even if Synesius later elaborated a real letter into the $E p .5$ we know (as his remark about saving the letter for his diary might imply, 25.15-15), he did nothing to change its chronological references. 
Ep. 5 itself cannot be dated with perfect exactness, but the possible dates for Synesius' "night of the conjunction" can be identified. If it could be assumed that Synesius reckoned or observed the conjunction with perfect accuracy, the astronomical and calendrical information of $E p .5$ describes 14 possible dates between 395 and 415, the chronological limits set by Roques. If allowances are made for the conditions Synesius actually faced, 44 dates are theoretically possible (see Appendix). Fortunately many of them can be excluded.

Synesius' debt to his Thracian host (Ep. 5.18.14-18) has always been identified with the debt to Proclus explained in Ep. 129, with which Synesius sends money to his Constantinopolitan friend Pylaemenes so that he will repay it for him (Ep. 129.220.8-12). The circumstances of the loan, described here, match his escape from Constantinople during an earthquake, described in $E p$. 61 . He raced to the harbor scarcely saying goodbye to anyone (Ep. 61.101.1-8) and manifestly not taking time to have so large a sum as sixty solidi sent to him from home. Synesius states specifically that he failed to take leave of

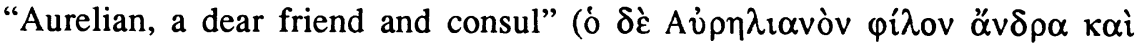

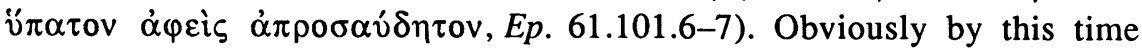
Aurelian had returned from exile, as Synesius describes in De Providentia 123D-124A (122.11-15 Terzaghi), so that Synesius can have departed no earlier than September or October of 400 . Seeck, to make Synesius' earthquake

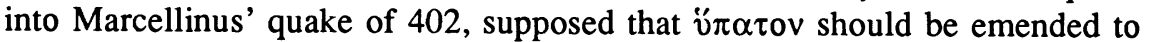
i $\pi \alpha \tau \iota \kappa o ́ v$ or $\ddot{\jmath} \pi \alpha \rho \chi 0 v .{ }^{44}$ But Barnes and Cameron both have shown that other evidence confirms the strict accuracy of Synesius' terminology in Ep. 61.45 Synesius left Constantinople during the year 400, when Aurelian was the Eastern consul. ${ }^{46}$ Therefore unless Synesius contracted another debt to a Thracian host, about which no evidence speaks, all dates for $E p .5$ before autumn 400 can be eliminated. Even 4 September 400 is too early to accommodate a journey from Constantinople to Alexandria and the adventures of Ep. 5.

Synesius' letters are dated between the later 390's and the first half of 413, according both to Roques (1989), the latest study of their chronology, and to previous scholarly consensus. Since Synesius wrote particularly actively during the last years of this period, 410 to 413 , his sudden silence thereafter

\footnotetext{
44Seeck, 458-62; Chron. Marc. s.a. 402, Chron. Min. II = MGHAA IX.67.

45Barnes (above, n. 33) 104 and passim; Cameron, 343 and passim.

${ }^{46}$ Cf. CLRE s.a. 400.
} 
has always seemed to mark his death. ${ }^{47}$ Astronomically possible dates in 414 and 415 may accordingly be eliminated.

As Roques noted, dates falling outside of the normal sailing season must be eliminated too. Synesius' ship was the first of five directed into the harbor near Azarium on the Thursday, and others joined them on the Friday (22.3-7): sea traffic was heavy. Yet the ancients considered sailing extremely unsafe during much of the year. They avoided the sea in winter. In 380 the emperors sought to avoid shipwrecks of the African grain fleet by restricting its sailing season between 13 April and 15 October. ${ }^{48}$ Writing in the late 380's or early 390 's, Vegetius states absolutely that "the seas are closed" (maria clauduntur, 4.39) from 10 November to 10 March. He judges that the safest season extends only from 27 May to 14 September. Doubtless the exact dates varied each year with the weather, but the law and Vegetius suggest approximately a range of time for Synesius' voyage. If many ships were sailing, the time is likely to have been closer to the favored period between later April or May and mid September or October than to the extremes of March and November. Dates before early March or after early November are definitely excluded.

Besides the volume of sea traffic, the large number of Synesius' fellow passengers, the fact that a substantial proportion of them were women (12.20), and the fact that reserves of food were not stocked (22.12) all suggest that the travelers expected a speedy journey, with no risk of storms. Roques however categorically excluded possible dates in June, July, August and September on the grounds that it never rains in Libya during these months. ${ }^{49}$ Recent research has tended to suggest that the climate of the Eastern Mediterranean fluctuated within the same ranges in antiquity as it does now, so that Lacombrade's

\footnotetext{
${ }^{47}$ Roques 1989, 247. Lacombrade, 252 and 273 underlined also the fact that Synesius alludes to the death of Theophilus of Alexandria (15 Oct. 412; Ep. 12.33.1-2 cf. 33.8), but never names his successor Cyril. W. Liebeschuetz, "The date of Synesius' de Providentia," Actes du VII' Congrès de la F.E.I.C. 2 (Budapest 1984) 39-46, esp. 40 and 42 n. 24, claimed that Prov. reflects the patrician Aurelian's return to the praetorian prefecture in 414 , which would mean that Synesius lived at least until then. But in fact, Synesius never says that his allegorical surrogate for Aurelian was restored to office after returning from exile in 400 .

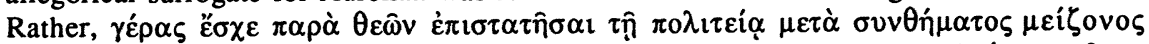
(Prov. 124C). Receiving a higher title is not the same as getting the old one back. $\dot{\varepsilon} \pi \iota \tau \alpha \alpha \tau \hat{\eta} \sigma \alpha \iota$ with the dative suggests merely informal influence (a suggestion of administrative competence would call for the stronger sense of the verb, with the genitive: LSJ s. v.).

${ }^{48}$ CTh. 13.9.3. Casson, Ships and Seamanship in the Ancient World (Princeton 1971) 27073 conveniently summarized and assembled bibliography about the ancient sailing season; see too Cameron, 355-6.

${ }^{49}$ Roques 1977, 280-81; Roques 1989, 182-3.
} 
objections to Roques' use of modern meteorological data have been answered;50 but even so, Roques insisted too rigidly on oversimplified information. It is true that only a narrow strip of the Libyan coast is primarily influenced by the weather patterns of the Mediterranean, and that even this region is influenced by Saharan desert weather too. It rains, on average, very little indeed during the summer months. But Synesius experienced his storms at sea, where if anywhere the wetter Mediterranean climate prevails. ${ }^{51}$ The climate of the inland desert is not at issue.

Moreover, even during the relatively dry coastal summer, rare downpours occur. 52 The meteorological data most relevant to Ep. 5 are not average rainfalls, but maximum amounts of rain observed to fall within a 24hour period. For the months of the ancient sailing season at locations along the coast between Cyrene and Alexandria, the following data are available to me:

$\begin{gathered}\text { Derna, Libya } \\ \text { (10-year observation } \\ \text { period) }\end{gathered}$
$\begin{gathered}\text { Sallum, Egypt } \\ \text { (20-year observation } \\ \text { period) }\end{gathered}$$\quad \begin{gathered}\text { Alexandria, Egypt (24- } \\ \text { year observation period) }\end{gathered}$

\begin{tabular}{|c|c|c|c|c|c|c|}
\hline month & mean total & $\begin{array}{c}\max . \text { in } 24 \\
\text { hours }\end{array}$ & mean total & $\begin{array}{c}\max . \text { in } 24 \\
\text { hours }\end{array}$ & mean total & $\begin{array}{c}\max . \text { in } 24 \\
\text { hours }\end{array}$ \\
\hline March & $28 \mathrm{~mm}$ & $23 \mathrm{~mm}$ & $12 \mathrm{~mm}$. & $30 \mathrm{~mm}$ & $12 \mathrm{~mm}$. & $13 \mathrm{~mm}$ \\
\hline April & $5 \mathrm{~mm}$ & $14 \mathrm{~mm}$. & $1 \mathrm{~mm}$. & $8 \mathrm{~mm}$. & $3 \mathrm{~mm}$. & $13 \mathrm{~mm}$. \\
\hline May & $10 \mathrm{~mm}$ & $25 \mathrm{~mm}$. & $3 \mathrm{~mm}$. & $16 \mathrm{~mm}$. & $2 \mathrm{~mm}$. & $9 \mathrm{~mm}$. \\
\hline June & & & & $1 \mathrm{~mm}$. & & $<1 \mathrm{~mm}$. \\
\hline July & $<1 \mathrm{~mm}$. & $1 \mathrm{~mm}$. & $0 \mathrm{~mm}$. & trace & $0 \mathrm{~mm}$. & trace \\
\hline August & $1 \mathrm{~mm}$ & $11 \mathrm{~mm}$ & $0 \mathrm{~mm}$. & $0 \mathrm{~mm}$. & $<1 \mathrm{~mm}$. & $9 \mathrm{~mm}$. \\
\hline September & $9 \mathrm{~mm}$. & $50 \mathrm{~mm}$. & $1 \mathrm{~mm}$. & $6 \mathrm{~mm}$. & $<1 \mathrm{~mm}$. & $4 \mathrm{~mm}$. \\
\hline October & $11 \mathrm{~mm}$ & $60 \mathrm{~mm}$ & $5 \mathrm{~mm}$. & $58 \mathrm{~mm}$ & $9 \mathrm{~mm}$. & $24 \mathrm{~mm}$. \\
\hline November & $57 \mathrm{~mm}$. & $62 \mathrm{~mm}$. & $28 \mathrm{~mm}$. & $121 \mathrm{~mm}$ & $29 \mathrm{~mm}$. & $32 \mathrm{~mm}$. \\
\hline
\end{tabular}

${ }^{50}$ The papers collected in Man's Role in the Shaping of the Eastern Mediterranean Landscape: Proceedings of the INQUA/BAI Symposium on the Impact of Ancient Man on the Landscape of the Eastern Mediterranean Region and the Near East, Groningen 6-9 March 1989, edd. S. Bottema, G. Entjes-Nieborg, W. van Zeist (Rotterdam 1990), for example, correlate soil erosion and related phenomena in prehistory and antiquity principally with intensive periods of human settlement. Most call for further studies, but thus far these researchers have not found evidence for significant climatic change. I am grateful to Archibald Warren Dunn for this reference.

${ }^{51}$ See J. F. Griffiths, Climates of Africa, World Survey of Climatology 10 (Amsterdam, London and New York 1972) 37. The climatological data that follow are drawn from page 59 tab. 19 on Derna, page 130 tab. 30 on Alexandria, and page 131 tab. 31 on Sallum; cf. page 55 tab. 15 (Sirte), page 57 tab. 17 (Benina = Benghazi), page 58 tab. 18 (Misurata), and page 124 tab. 24 (Kufra). Cf. D. L. Johnson, Jabal al-Akhdar, Cyrenaica: an Historical Geography of Settlement and Livelihood, U. Chicago Dept. Geography Research Paper 148 (Chicago 1973), esp. 10-14.

${ }^{52}$ Cf. Johnson (above, n. 51) 14-16. 
Isolated rainstorms along the coast between Alexandria and Cyrene, when they occur, can produce more rain in one day than normally falls in entire months. The figures suggest that Synesius was less likely to suffer rain throughout a night in June or July than in other months during which he might have been sailing, but not even these months may wholly be excluded from possibility.

These considerations reduce the list to eighteen possible dates between 29 May 401 and 12 August 413, eliminating winter months when the seas were closed. Of these eighteen, 11 November 402, 8 November 405 and 4 November 408 coincide closely with Vegetius' dates for the closing of the sailing season: in any given year the seas may have been calm then, but the dates seem too near periods of well-known danger for the sea traffic Synesius describes or the improvident confidence of his fellow passengers. Similarly, it is barely possible that an unusually fine early spring might have sent a few ships sailing under the conjunction of 6 March 406, but the normal expectations for such a date do not match well with Synesius' account. Of the remaining fourteen dates, protracted rains are less likely on 16 July 402, 12 July 405, 10 June 408 or 28 July 409.

At this point the argument becomes more intricate. As far as Synesius can have known, he had safely discharged his debt to Proclus as soon as he sent money to him. From then on he had no reason to fear defaulting as a consequence of drowning in Amarantus' ship. Therefore Ep. 5 must antedate his payment. In Ep. 129 he explains to Pylaemenes that his first attempt failed. He himself had recently tried to travel to Constantinople when bad weather forced the ship to land at Alexandria. On arrival he found that all his letters to Pylaemenes from the past year and his original repayment to Proclus had similarly been diverted. Now he sends the whole packet of letters again. He adds $E p .129$ as a bonus, and ten solidi evidently replacing a gift of ostriches which he had meant to bring to Constantinople with him. ${ }^{53}$ For Proclus he now sends eighty solidi, the sixty he had borrowed plus, "as Hesiod directs, a third

${ }^{53} E p .129 .220 .19-221.1$. The ostriches suggested to Roques 1989,121 that Ep. 129 was written later than Ep. 134, in which Synesius says he is presently unable to send Pylaemenes some ostriches, but will ship them eventually $(233.14-16,234.13-14)$. Yet it is equally possible that $E p .134$ is later and Synesius records a new deferral of the gift. No other points of similarity between the letters reinforce Roques' link. Synesius mentions sending wine to Proclus, not his debt (Ep. 134.234.6-8). The conveyance of letters $\pi \rho \omega ́ \eta \nu$ by Synesius' relation Diogenes (233.4-12; doubtless featutring the recommendations Epp. 119, 131), pace Roques 1989, 123, does not match Synesius' own arrangements at Phycus for letter-carrying as reported in Ep. 129 (219.15-220.1). 
of the debt again." 54 Between Synesius' discovery and the sending of Ep. 129 his sense of shame might have returned, but the interval seems to have been brief and Synesius to have remained safely in Alexandria the while. Ep. 5 was written not only before $E p$. 129, but also before Synesius first tried to repay Proclus.55

There is no direct evidence of when Synesius made this attempt. Ep. 129 is a terminus ante quem, but defines for itself only a terminus post quem. Synesius found at Alexandria a full year's output of his letters (219.10), which he had sent from Phycus (219.15-220.1): therefore Ep. 129 was written after a full year's stay in Cyrene following his return from Constantinople. ${ }^{56}$ Ep. 129 implies that Synesius attempted to right his debts as soon as he could. ${ }^{57}$

In Ep. 61 Synesius settles another obligation incurred on his embassy. He had promised a rug to the tachygraphos Asterius ${ }^{58}$ but did not have time when he left to give it to him. Now, since ó $\pi$ ó $\lambda \varepsilon \mu o \zeta$ leaves him little time to write (102.12), he asks Pylaemenes to convey both rug and apologies. Seeck and Lacombrade each assumed that Synesius sent the rug back to Constantinople immediately after he himself returned home. ${ }^{59}$ Roques however supposed that

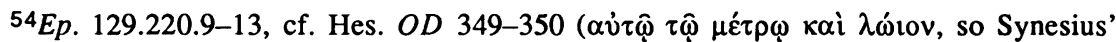
$\tau \rho ı \tau \eta$ ópı $\alpha$ is his own idea; Roques' uneven sums [1989, 185] demonstrate that it is not based

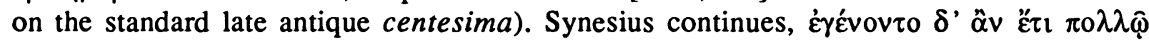

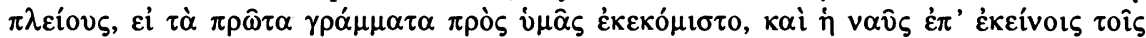

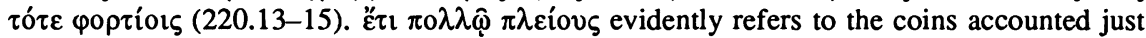

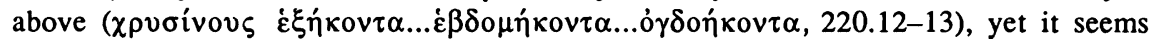
bizarre for Synesius to pay less after a delay than he had originally. He doubles the interest Proclus had proposed to charge him. Roques, $i b$. , strangely translated "la somme que le Cyrénéen a renvoyée devait être 'beaucoup plus importante." Perhaps Synesius alludes to a proverb related to Pub. Syr. B1, D19, I6 and to $A P 10.30$, on the added value of prompt payment (in Publilius' versions, "doubled"): cf. B. Stevenson, The Home Book of Proverbs, Maxims and Familiar Phrases (New York 1948) 956, esp. items II.3, 7.

${ }^{55}$ Roques 1989, 186 overlooked this consideration and dated Ep. 129 some months before $E p .5$, the one reflecting his arrival in Alexandria and the other his departure on the same visit (the second quarter of 407 and 23 October 407 respectively, cf. Roques 1989, 130-31; Roques 1977, 288-93).

${ }^{56}$ Roques 1977, 288-93 and 1989, 129 unwarrantably supposed that Synesius complains of waiting a full year without a letter from Pylaemenes. Synesius mentions a letter from him (220.6-8), and regrets only that his own letters were not delivered: غ́vı $\alpha v \tau$ òv ő $\lambda$ ov

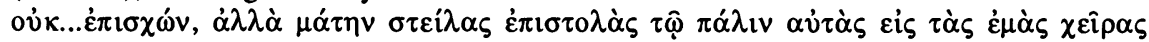
$\dot{\alpha} v \alpha \kappa о \mu \iota \sigma \theta \hat{\eta} v \alpha \imath, 219.10-12$.

${ }^{57}$ So e.g. Seeck, 469. Of course, as Roques 1989, 184 warned, Synesius was bound to represent the circumstances of his repayment favorably to himself; on the other hand Roques assumed wildly that Synesius in Ep. 129 overpays his original bond because he pays late, but partially defaults on overdue interest (arbitrarily calculated, 185).

${ }^{58}$ See PLRE II.171, "Asterius 2."

${ }^{59}$ Seeck, 470-71; Lacombrade, 136. 
every reference in Synesius' letters to war must mean the barbarian incursions into Cyrene which he considered to have begun only in $405.60 \mathrm{He}$ dated Ep. 61 accordingly $(1989,184,197)$. On his chronology, Asterius had to wait for his rug three years. Roques confirmed this interval by arguing that Synesius means by "the third voyage [of] this vessel to Thracian districts since my return from there" the third annual grain shipment from Alexandria to Constantinople.61 But this interpretation jars against the genitive of agent with which Synesius

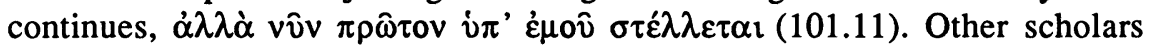
have better understood indefinitely scheduled sailings of a particular boat. ${ }^{62}$ Moreover, Synesius left Constantinople in 400, not 402. Roques' argument cannot explain a five-year interval. ó $\pi$ ó $\lambda \varepsilon \mu \rho_{\zeta}$ must refer to a different conflict. If so, there is no reason to reject the natural implications of Synesius' claim to be sending the rug at the first occasion possible (101.12) and his confidence that his haste in leaving Constantinople sufficiently explains what delay there has been (101.6-8, cf. 102.9-11).

The delay was not excessive in the context of late antique Mediterranean travel. But what does that mean? Synesius imagines it possible that since his departure Asterius might have advanced from third or fourth within his division of tachygraphoi to first (102.7-8). The potentiality, vvvi $\delta \varepsilon \dot{\varepsilon}$ kồ

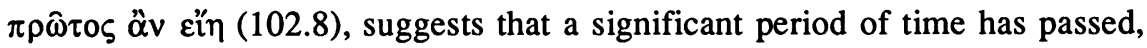
but adverbial $\kappa \alpha i$ weakens the potential optative, and seems to shorten the likely interval. A. H. M. Jones plausibly identified Asterius as an exceptor. ${ }^{63}$ If so, the two-year maximum term for the primicerii of palatine scrinia set by CTh. 6.30 .14 of 396 implies that Synesius must have written within six years. By then, however, he should have been certain that Asterius was first. This doubt too shortens the interval. Moreover, Synesius could easily have known of political considerations, or factors such as the health of Asterius' seniors, that might have been expected to speed his advancement. It seems prudent to allow an interval of one or two years.

Synesius' debt to Proclus was far greater than Asterius' rug. With Proclus' wealth came influence: Synesius must have wanted to preserve his good will by discharging his debt promptly. Whereas Asterius vanishes after

${ }^{60}$ Roques $1989,65-75$; he allowed the possibility of "simples menaces" between 398 and 405.

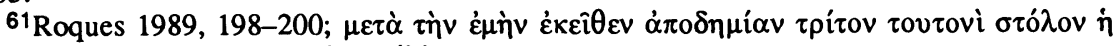

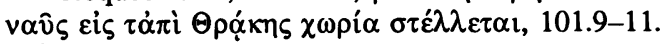

62E.g. Druon, 449 and 589; A. Fitzgerald, The Letters of Synesius of Cyrene (London 1926) 145; Garzya, Opere di Sinesio di Cirene (Turin 1989) 62.

${ }^{63}$ A. H. M. Jones, The Later Roman Empire 284-602 (1964; rpt. Baltimore 1986) $1243 \mathrm{n}$. 60 ; cf. the passages of Joh. Lyd. Mag. cited there and Jones pages 584-5, 588, 1241 n. 51. 
Ep. 61, in Epp. 70 and 134 as well as 129 Synesius continues to cultivate Proclus with letters and presents. His attempt to repay his loan should be dated no later than Ep. 61. A range of no more that six years for Asterius' promotion and the sending of Ep. 61 leaves the nights after the Tuesdays 28 May 401, 22 October 401, 7 April 403, 24 May 404, and 20 September 404 as the most eligible dates for the conjunction of $E p$. 5, with the nights after the Tuesdays 15 July 402, 11 November 402, 11 July 405, 7 November 405 and 6 March 406 probably to be excluded according to observed weather patterns and the established sailing season.

The simplest way of fitting Ep. 5 in with the other events is to assume that Synesius sailed from Constantinople to Alexandria in late autumn 400, waited out the closed seas of winter, and endured the nautical mishaps of Ep. 5 on his way home to Cyrene in the next year. Roques $(1989,184)$ pointed out that sea routes lie as directly from Constantinople to Cyrene as to Alexandria, so that Synesius might in theory have sailed straight home; nevertheless, leaving Constantinople as he did in an emergency and late in the sailing season, he is far likelier to have been able to find a ship sailing to the Egyptian capital than to a lesser city. The delays of winter and shipwreck account for some interval between Synesius' leaving Constantinople and sending Ep. 61 .

Separate, religious considerations harmonize with this sequence. Synesius' Hymn 1 celebrates his return, after his three miserable years in Thrace, to the beloved countryside of Libya where he will receive on his soul the "seal of the Father" ( $\sigma \varphi \rho \alpha \gamma \hat{i} \delta \alpha \pi \alpha \tau \rho o ́ \zeta, H .1[3] .621)$. Synesius describes himself as coming directly from Thrace to pay a religious debt, which suggests that his intention was formed in Constantinople (H. 1[3].429-441; cf. 442-495). He had time en route to explain his plans to Euoptius. $\sigma \varphi \rho \alpha \gamma i \varsigma$ has been linked with the terminology of the Chaldaean Oracles, but significantly it was in Synesius' period a standard Christian figure for baptism. ${ }^{64}$ The most straightforward interpretation of the hymn is that Synesius chose to be baptized as soon as he returned home. As he prays for the protection of the "seal," he also renounces the allurements that draw his soul to the earth $(H .1[3] .646-691)$. This rejection accords with Synesius' insistence in $E p .5$ that he avoids incriminating contact

${ }^{64}$ Chaldaean connection: A. Jahn, Eclogae e Proclo de Philosophia Chaldaica (Halle 1891) 71; W. Theiler, Die chaldäische Orakel und die Hymnen des Synesios (Halle 1942) 36-37; E. des Places, Oracles chaldaïques (Paris 1971) 40; Lacombrade, Synésios de Cyrène: Hymnes (Paris 1978) 57. Christian term: F. J. Dölger, Sphragis, eine altchristliche Taufbezeichnung in ihren Beziehung zur profanen und religiösen Kultur des Altertums (Paderborn 1911); Lampe, Patristic Lexicon s. vv. $\sigma \varphi \rho \alpha \gamma i \varsigma, \sigma \varphi \rho \alpha \gamma i \zeta \omega$. J. Bregman, Synesius of Cyrene: PhilosopherBishop (Berkeley 1982) 91-92 illustrates the confusion resulting from the assumption that Synesius cannot be making a Christian reference. 
with the female travelers. Notably, he anticipates that he shall have to "forswear" such contact (24.3). Ep. 5 thus places itself in sequence after Synesius' embassy and a visit with Euoptius in Alexandria and before his return to Cyrene and baptism. The "Roman monk" together with whom Synesius eats limpets in the harbor at Azarium may well have a role in these religious plans. ${ }^{65}$

Several stages in Synesius' reconstructed itinerary have only vague chronological limits. He fled from Constantinople to Alexandria late in the sailing season of 400 . He visited with Euoptius and other friends in Alexandria at least through the winter. His journey back to Cyrene was interrupted twice; it is impossible to tell how long he spent stranded in Azarium. Finally he did return home and fulfilled the vows alluded to in Hymn 1. Some considerable but not socially heinous period after his departure from Constantinople, perhaps a year or two but certainly no more than than six years, he sent back the rug for Asterius and the money he owed Proclus. The latter shipment was halted in Alexandria. Synesius himself, after staying at least a full year in Cyrene, attempted to travel to Constantinople but was blown off course. This detour could have inaugurated the two-years' visit to Alexandria Synesius mentions in Ep. 123: there are no indications that he had planned it in advance. He sent Proclus' money on again.

The night after Tuesday 28 May 401, Vogt's and Cameron's date for the stormy "night of the conjuction" on which Synesius' ship faced its second crisis, is the earliest of my list that remains possible. It falls just at the beginning of the period Vegetius defines as best for sailing, and yet during a season when modern meteorological observations definitely attest occasional heavy rains along the Libyan coast. Thus it suits well the sailing conditions Synesius describes. On the other hand, this schedule would have made Synesius miss Easter, the standard occasion for baptism, by the almost perversely narrow margin of a month and a half: in 401 it fell on 14 April.66 If Hymn 1 affords any legitimate grounds for chronological inference, it might seem to suggest that his petition for the "seal" followed his return to Cyrene more closely than Easter a year later. This schedule also leaves unexplained Synesius' delay in sending Asterius his rug.

Presuming that Synesius stayed longer in Alexandria mitigates this difficulty. It is not too hard to believe that he postponed his vow an extra year hoping, vainly, to avoid rough weather on his trip home. If any merit can be

${ }^{65}$ Ep. 5.23.1; cf. above, n. 42.

${ }^{66} \mathrm{~F}$. K. Ginzel, Handbuch der mathematischen und technischen Chronologie III (Leipzig 1906-1914) 411 (tab. 3). 
squeezed into Roques' interpretation of Garzya's emendation (20.10) by assuming that Synesius could refer to evening risings of the constellations, it points to the night after Tuesday 22 October 401 . Synesius would have seen the Pleiades rise at nightfall on October 7 or 8.67 With the list now bounded by expectations for Asterius' promotion, only this conjunction remains between the first week of October and the end of the sailing season; the nights after Tuesday 11 November 402 and Tuesday 7 November 405, as noted above, are too close to bear belief. This late sailing would also neatly force payment of Synesius' debts into the range of time deemed likely for Ep. 61. Especially after additional delay at Azarium, it is most improbable that Synesius would have entrusted anything to the seas until the next spring. During the winter he also began to accumulate his full year's output of letters to Pylaemenes. Ep. 129 could date either to fall of 402 or spring of 403 .

I consider the nights of 28 May and 22 October 401 to be the most likely candidates for the conjunction of Ep. 5. Later dates require Synesius to have stayed more than a year in Alexandria on his way home, or else to have gone home and then to Alexandria before sending any money to Proclus. Either hypothesis seems awkward, and grows worse with later times. These factors weigh against the assumption that Synesius calculated rather than observed his astronomical dates; on that ground the night after Tuesday 7 April 403 is the earliest possible. It and the nights after Tuesday 24 May 404 and Tuesday 20 September 404 are not excluded climatologically, though less attractive by their lateness. By fall 406 at the latest, the regular rotation of primicerii of Asterius' division must have brought him to first place even from fourth; later dates for $E p .61$ and by analogy for Synesius' first attempt to repay Proclus, an event which Ep. 5 must antedate, are not credible.

Euoptius saw Synesius off at the harbor, so he knew precisely when the voyage of $E p .5$ took place (11.6-9). He could enjoy the tale of superstitions, disasters and rescues for what it was: art and erudition reworking a terrible trip into an amusing story. The goal of finding a precise date for an ancient event should not obscure the primary, literary function of the letter. Nevertheless it does pose a fascinating puzzle of philology, calendars, astronomy, climatology and history combined. I have tried to build on the work of Seeck, Grützmacher, Hermelin, Lacombrade, Vogt, Roques and Cameron by coordinating these researches systematically. I have underlined and respected the limitations of both evidence and methodology, so as to find a date for $E p .5$ as conclusively as is truly possible.

${ }^{67}$ Gundel, "Pleiaden," RE 21, 2.2503. 
My dates in May or October 401 for Synesius' voyage of Ep. 5 carry after them into 402 Synesius' baptism, his first attempt to repay Proclus and his forwarding his rug to Asterius with Ep. 61. Synesius may therefore be released from Roques' charge that he only tried to repay Proclus several years late and sought to evade a substantial portion of his debt. Such gross delinquency by so active a participant as Synesius in the late antique network of patronage would have required explanation. Ep. 129 repairs inadvertent delinquency. On my argument it dates either to autumn of 402 or to spring of 403. It seems to mark an early point in the two-year stay in Alexandria that Synesius mentions in Ep. 123; therefore this visit spans either $402-403$ or $403-404,68$ and Ep. 123 must have been sent as soon as the sailing season permitted it after Synesius' return. This argument already demonstrates the close interrelationship of groups of Synesius' letters; Roques' study shows that Synesius' whole biography depends upon interrelationships extending across his whole corpus. The correction of these dates requires others to be shifted, which will in turn move others. That work extends beyond the scope of this article, but only by such corrections will we obtain a complete picture of the activities and concerns of this provincial nobleman. Such an understanding will illuminate his class, his region, and his insights into national politics. Ep. 5 in its artistry also promises inherent charm to the investigation.

${ }^{68}$ Both baptism on Easter 402 and Synesius' one-year accumulation of letters to Pylaemenes from Cyrene ( $E p .129 .219 .10)$ preclude a two-year's visit to Alexandria in 401-402, against Cameron, 357. 


\section{Appendix: Theoretically Possible Dates for the Conjunction of} Ep. 5

The dates in this list were generated by matching Synesius' account of days and the conjunction with the tables of H. H. Goldstine, New and Full Moons 1001 B.C. to A.D. 1651, Mem. Amer. Philos. Soc. 94 (Philadelphia 1973) and The World Almanac and Book of Facts 1990, ed. M. S. Hoffman (New York 1989), 266-8. It includes all the new-moon conjunctions falling on the night between a Tuesday and a Wednesday, between 395 and 415 . I observe the limits set by Roques in his article of 1977 , in order that my results may be compared with his most readily.

In order to account for conjunctions that occurred during daylight hours, I assume that conjunctions occurring before noon were most nearly observable on the preceding night, and conjunctions occurring after noon were most nearly observable on the following night. This assumption risks error most when a conjunction occurs close to noon, particularly since the uniform hours in which Goldstine expressed the times of conjunctions diverge slightly from the divisions of daylight about the true noon which Synesius observed. Here too it becomes significant that "the real times of the new and full moons may differ from the computed times by 10 or 20 minutes or even more because of the irregular rotation of the earth." 69 This inescapable inaccuracy, rare and minor compared to the inaccuracies of Couderc's table, may mean that Synesius could have observed certain conjunctions a night earlier or later than my approximation to the nearest night suggests. Accordingly I list approximations in both directions for conjunctions occurring within two hours of noon.

Finally, the fact that we do not know precisely where Synesius was on "the night of the conjunction" also affects the list of possible dates. ${ }^{70}$ Goldstine calculated the conjunctions in the civil time of Babylon, that is, relative to the appearance of the sun there. Synesius was somewhere off the coast between Alexandria and Cyrene: he observed the diurnal cycle of the sun approximately an hour later in absolute terms. Therefore according to his own perception of the time of day, the conjunction occurred approximately one hour earlier. I therefore subtract an hour from Goldstine's times to make up my list. But since the precise difference cannot be ascertained, the times may be slightly inaccurate. The two-hour ambiguity I allow for conjunctions occurring close

\footnotetext{
${ }^{69}$ B. L. van der Waerden, review of Goldstine, Isis 65 (1974) 407.

${ }^{70} \mathrm{Cf}$. above, $\mathrm{n}$. 20 . This paper has profited throughout from the comments of TAPA's editor and referees; I thank them warmly.
} 
to noon is far greater than this possible inaccuracy, however, so that no further adjustment is necessary.

In this table an asterisk denotes a conjunction which matches Synesius' description with the full precision of modern calculation: on the 28th of a 29day lunar month with a full moon on the 15 th, as reckoned in the evening epoch, or on the 29th of a 30-day lunar month with a full moon on the 16th. Parentheses denote a date where the conjunction falls close to noon and though better identified with a different night, might nonetheless be perceived on a night between Tuesday and Wednesday.

Date

Time

Day and Date

(midnight epoch)

(24 uniform-hour clock,

(morning epoch) midnight epoch)

\begin{tabular}{|c|c|c|}
\hline (T 6 February 395) & (11.32) & $\begin{array}{l}\text { (night after M } 5 \text { February } 395 \text { or } \\
\text { n.a. T } 6 \text { Feb. 395) }\end{array}$ \\
\hline *T 3 July 395 & *19.02 & 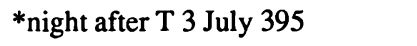 \\
\hline T 30 October 395 & 12.30 & $\begin{array}{l}\text { night after T } 30 \text { October } 395 \text { (or } \\
\text { n.a. M } 29 \text { Oct. } 395 \text { ) }\end{array}$ \\
\hline T 25 March 396 & 21.57 & night after T 25 March 396 \\
\hline *W 20 August 396 & $* 2.54$ & *night after T 19 August 396 \\
\hline W 17 December 396 & 2.06 & night after T 16 December 396 \\
\hline *W 13 May 397 & $* 5.59$ & *night after T 12 May 397 \\
\hline (W 30 June 398) & (12.39) & $\begin{array}{l}\text { (night after W } 30 \text { June } 398 \text { or n.a. } \\
\text { T } 29 \text { June } 398 \text { ) }\end{array}$ \\
\hline T 22 February 399 & 12.07 & $\begin{array}{l}\text { night after T } 22 \text { February } 399 \text { (or } \\
\text { n.a. M } 21 \text { Feb. 399) }\end{array}$ \\
\hline T 19 July 399 & 13.09 & $\begin{array}{l}\text { night after T } 19 \text { July } 399 \text { (or n.a. } \\
\text { M } 18 \text { July } 399 \text { ) }\end{array}$ \\
\hline *T 13 December 399 & *23.25 & 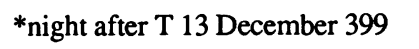 \\
\hline T 10 April 400 & 21.38 & night after T 10 April 400 \\
\hline T 4 September 400 & 22.04 & night after T 4 September 400 \\
\hline (W 30 January 401) & (13.25) & $\begin{array}{l}\text { (night after W } 30 \text { January } 401 \text { or } \\
\text { n.a. T } 29 \text { Jan. } 401 \text { ) }\end{array}$ \\
\hline W 29 May 401 & 4.57 & night after T 28 May 401 \\
\hline W 23 Oct 401 & 8.58 & night after T 22 Oct. 401 \\
\hline (W 16 July 402) & $(12.16)$ & $\begin{array}{l}\text { (night after W } 16 \text { July } 402 \text { or n.a. } \\
\text { T } 15 \text { July } 402 \text { ) }\end{array}$ \\
\hline [ 11 November 402) & (11.24) & $\begin{array}{l}\text { (night after M } 10 \text { November } 402 \\
\text { or n.a. T } 11 \text { Nov. } 402 \text { ) }\end{array}$ \\
\hline *T 7 April 403 & *19.05 & 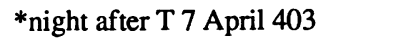 \\
\hline W 30 December 403 & 0.51 & night after T 29 December 403 \\
\hline *W 25 May 404 & $* 2.57$ & 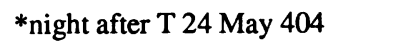 \\
\hline
\end{tabular}


T 20 September 404

(W 15 February 405)

*W 12 July 405

W 8 November 405

T 6 March 406

*T 17 September 407

T 14 January 408

W 10 June 408

*W 4 November 408

W 3 March 409

(W 28 July 409)

*W 20 April 410

T 16 August 410

*T 10 January 411

T 3 October 411

*W 28 February 412

W 20 November 412

T 12 August 413

T 9 December 413

T 5 May 414

*W 30 September 414

W 27 January 415

*T 22 June 415
14.58

*9.34

4.10

14.04

$* 16.00$

12.55

5.58

*3.57

1.38

$* 10.24$

12.59

*17.51

22.49

$* 5.21$

11.48

16.54

12.07

13.44

*3.34

1.02

*20.29 night after T 20 September 404

(night after W 15 February 405 or n.a. T 14 Feb. 405)

*night after T 11 July 405

night after $T 7$ November 405

night after T 6 March 406

*night after T 17 September 407

night after T 14 January 408 (or n.a. M 13 January 408)

night after $\mathrm{T} 9$ June 408

*night after T 3 November 408

night after T 2 March 409

(night after W 28 July 409 or n.a. T 27 July 409)

*night after T 19 April 410 (or n.a. W 20 April 410)

night after $T 16$ August 410 (or n.a. M 15 August 410)

*night after T 10 January 411

night after $\mathrm{T} 3$ October 411

*night after T 27 February 412

night after $T 19$ November 412 (or n.a. W 20 Nov. 412)

night after T 12 August 413

night after $\mathrm{T} 9$ December 413 (or n.a. M 8 Dec. 413)

night after T 5 May 414 (or n.a. M 4 May 414)

*night after T 29 September 414

night after $\mathrm{T} 26$ January 415

*night after T 22 June 415 


\section{Works Cited}

Bickerman2: E. J. Bickerman, Chronology of the Ancient World, 2nd ed. (Ithaca NY 1980).

Bobrovnikoff: N. T. Bobrovnikoff, Astronomy before the Telescope I: The Earth-Moon System, edd. R. B. Culver and D. D. Meisel, History of Astronomy Series I (Tuscon 1984).

Cameron: A. Cameron, "Earthquake 400," Chiron 17 (1987) 343-60.

Druon: H. Druon, Oeuvres de Synésios (Paris 1878).

Garzya 1978: A. Garzya, "Problèmes textuels dans la correspondance de Synésios," Byz. Stud./Etudes Byz. 5 (1978) 125-36.

Goldstine: H. H. Goldstine, New and Full Moons 1001 B.C. to A.D. 1651 Mem. Am. Philos. Soc. 94 (Philadelphia 1973).

Hermelin: I. Hermelin, Zu den Briefen des Bischofs Synesios (Uppsala 1934).

Lacombrade: C. Lacombrade, Synésios de Cyrène, hellène et chrétien (Paris 1951).

Neugebauer: O. Neugebauer, A History of Ancient Mathematical Astronomy, Sutides in the History of Mathematics and Physical Sciences I (New York, Heidelberg, Berlin 1975), 3 vols.

Roques 1977: D. Roques, "La lettre 4 de Synésios de Cyrène," REG 90 (1977) 263-95.

Roques 1989: D. Roques, Etudes sur la Correspondance de Synésios de Cyrène, Collection Latomus 205 (Brussels 1989).

Samuel: A. E. Samuel, Greek and Roman Chronology, Handbuch der Altertumswissenschaft 1, 7 (Munich 1972).

Seeck: O. Seeck, "Studien zur Synesius," Philologus 52 (1894) 442-83.

Vogt: J. Vogt, "Synesios auf Seefahrt," Kyriakon: Festschrift Johannes Quasten edd. P. Granfield and J. A. Jungmann, I (Münster Westfalen 1970) 400-08. 